\title{
Unbundling of Insurance Contracts for Accounting and Tax Purposes - One Common Solution for two Problems
}

\author{
Otto A. Altenburger, Max Goettsche, Magdalena Kuntner
}

Department of Financial Accounting, University of Vienna

\begin{abstract}
Insurance contracts often - or even regularly - contain both an insurance component and a so-called deposit component, i.e., they combine insurance coverage with a certain kind of saving process. Due to this feature insurance contracts are difficult to report on in financial statements and difficult to tax. The IASB's recent Discussion Paper Preliminary Views on Insurance Contracts (which has also been made part of a FASB's Invitation to Comment) requires an insurer to unbundle those components under certain conditions, since the failure to unbundle could lead to the complete omission of material contractual rights and obligations from the balance sheet. In this regard, unbundling refers to accounting for the deposit component separately from the insurance component as if they were independent contracts. However, the Discussion Paper does not contain any relevant guidelines on how the process of unbundling shall be carried out. Therefore, the proposed regulations pose severe applicability problems. For tax purposes, a workable method of unbundling insurance contracts has eluded tax authorities for decades. However, taxing life assurance premiums containing large deposit components with VAT as a whole would not be appropriate since that would not fit into the VAT system. Therefore, the insurance component and the deposit component have to be separated in order to be able to treat them individually. This paper develops a common solution for the separation problem in accounting and in taxation which is innovative, theoretically correct and practically applicable. The principal design innovation is the way of distinction of different deposit components and their classification into different types. Dividing them into 'implicit' and 'explicit' deposit components delivers the theoretically correct results for unbundling of insurance contracts both for accounting and tax purposes.
\end{abstract}




\section{Introduction}

Insurance contracts often - or even regularly - contain a so-called deposit component, i.e., they combine insurance coverage with a certain kind of saving process (Farny, 2000). ${ }^{1}$ Due to this feature insurance contracts are difficult to report on in financial statements and difficult to tax. Whereas insurance coverage means a constant flow of service from the insurance company to the insured for which the insured has to pay premiums per unit of time, the deposit component typically results in assets of the insured and liabilities of the insurance company. Therefore, it is not appropriate to treat the whole premium of a 'combined' contract in the same way, e.g., to recognise it as revenue or to take it as tax base for sales tax, especially for value added tax (VAT). The basic problem lies in the fact that premiums for 'combined' contracts are offered, negotiated, defined and paid as total amounts and cannot easily be split up into an insurance and a savings part, i.e., the deposit component of the contract cannot easily be distinguished from the insurance component of the contract. Nevertheless, two components have to be separated in order to be able to treat them individually.

In accounting, this separation is referred to as 'unbundling'. It means accounting for the components of a contract as if they were separate contracts. The term 'unbundling' can also be used in taxation because for tax purposes no other technical term exists.

The International Accounting Standards Board (IASB) published a Discussion Paper entitled Preliminary Views on Insurance Contracts ('the DP') in May 2007 which contains proposals for unbundling the insurance component and the deposit component of an insurance contract. However, the DP does not contain any guidelines on how the process of unbundling shall be carried out. Therefore, the proposed regulations pose severe applicability problems.

For tax purposes, a workable method of unbundling insurance contracts has eluded tax authorities for decades.

The objective of this paper is to develop a solution for the separation problem which is applicable both for accounting and for tax purposes. For practical reasons it seems to be desirable to find one common solution for unbundling in accounting and in taxation. Different boundaries between insurance and deposit components of the same contracts in accounting and in taxation would result in a heavy confusion of insurance companies and all other parties concerned. This paper presents an approach to unbundle insurance contracts by structuring and analysing the different components of insurance contracts. The approach suggested here is designed to overcome the fundamental difficulties of unbundling by using the criteria 'degree of dependency between the components' and 'arbitrariness of the measurement of the components' which are referred to by the IASB's DP for the decision whether to unbundle insurance contracts which contain a deposit component. Our solution will follow these criteria in order to be compatible with the IASB's regulations.

This paper makes several contributions to the literature. First, we examine whether it is theoretically and technically possible to unbundle the insurance component and the deposit component of an insurance contract for accounting and tax purposes. Second,

\footnotetext{
1 Barham, Poddar \& Whalley (1987) generally conclude that life insurance always comprises a 'substantial savings element', whereas pure insurance only includes a small savings element which results from the advance payment of the premium. Of different opinion are Boadway \& Keen (2003) who argue that pure insurance contains no 'savings element'. Equally Schmidt (1999) who argues that in the case of assurance of death risk the premium includes no savings element.
} 
we are the first to differentiate between 'implicit' and 'explicit' deposit components to develop a solution for the separation problem. Therefore, we are the first to design a workable approach for unbundling insurance contracts applicable both for accounting and for tax purposes.

The remainder of the paper proceeds as follows: The next section provides the background of the paper, describing the need for unbundling of insurance contracts for both accounting and tax purposes. Section 3 summarises the IASB's and the European Commission's proposals concerning unbundling of insurance contracts. The existing contributions of the literature to a solution of the separation problem are described in section 4, while section 5 presents our approach for unbundling the insurance components and the deposit components of insurance contracts. The final section contains the conclusions of the present study.

\section{Background}

\subsection{The Need for Unbundling of Insurance Contracts for Accounting Purposes}

The IASB is currently developing a new International Financial Reporting Standard (IFRS) on accounting for insurance contracts. In March 2004 the IASB issued the interim standard IFRS 4 Insurance Contracts as the result of phase I of the project on insurance contracts, which was originally initiated by the IASB's predecessor, the International Accounting Standards Committee (IASC), in 1997. As a first stage of phase II, the IASB released the above-mentioned DP on 3 May 2007 which shall lead to a new standard on accounting for insurance contracts. The DP presents the IASB's preliminary views on the main components of an accounting model for insurance contracts. It was open for comments until 16 November 2007. The projected timetable for the new standard on insurance contracts is shown in table 1:

\section{Table 1 goes about here}

Both in IFRS 4, Appendix A and in the DP, Appendix I an insurance contract is defined as follows: 'A contract under which one party (the insurer) accepts significant insurance risk from another party (the policyholder) by agreeing to compensate the policyholder if a specified uncertain future event (the insured event) adversely affects the policyholder.' In this context, the IASB refers to insurance risk as the 'risk, other than financial risk, transferred from the holder of a contract to the issuer' (IFRS 4, Appendix A and DP, Appendix I), whereas financial risk is 'the risk of a possible future change in one or more of a specified interest rate, financial instrument price, commodity price, foreign exchange rate, index of prices or rates, credit rating or credit index or other variable, provided in the case of a non-financial variable that the variable is not specific to a party to the contract' (IFRS 4, Appendix A).

By means of these definitions the IASB clearly distinguishes insurance contracts from investments and deposits which include financial risk only and therefore fall under the scope of IAS 39 Financial Instruments: Recognition and Measurement instead of IFRS 4. 
Deposit components of insurance contracts would fall under the scope of IAS 39 if they were separate instruments. ${ }^{2}$ Not accounting for the deposit components separately could lead to the following scenario: The insurer does not account for the deposit component of an insurance contract in the same way as for a separate, but otherwise identical, financial instrument that does not transfer significant insurance risk. Consequently, due to different measurement models in existing IFRSs, a deposit component of an insurance contract may not receive the same accounting treatment as a separate deposit contract. ${ }^{3}$

To avoid or minimise such accounting inconsistencies some argue that an insurer should account for any deposit component separately from the insurance component. ${ }^{4}$ Such unbundling has both measurement and presentation consequences which are described in detail in paragraph 223(a) and (b) of the DP and illustrated in table 2:

\section{Table 2 goes about here}

In IFRS 4.BC45 the IASB emphasises that unbundling is of particular importance for large customised contracts, such as some financial reinsurance contracts, because in these cases the failure to unbundle these contracts could lead to the complete omission of material contractual rights and obligations from the balance sheet. IFRS 4.IG5 provides an example for unbundling a deposit component of a reinsurance contract where the reinsurer is obliged to refund the premium to the cedant at the end of the contract in case of a positive experience account balance. The reinsurer is required to unbundle the contract if the reinsurer's accounting policies would not require the separate recognition of the contractual liability to repay the premium to the cedant.

Although the same principles could be applied to direct insurance contracts, the process of unbundling is more complex in these cases and poses very interesting detail questions. Despite this, or actually because of it, the present analysis is carried out from the perspective of a direct insurance contract with an individual policyholder whereas problems arising in the context of reinsurance contracts are explicitly left aside.

In August 2007 the FASB published an Invitation to Comment entitled An FASB Agenda Proposal: Accounting for Insurance Contracts by Insurers and Policyholders which includes the IASB's DP as Appendix C. The FASB requested comments on its proposal by 16 November 2007 to gather information from its constituents to help to decide whether there is a need for a project on accounting for insurance contracts. It also asked whether the IASB's preliminary views on insurance contracts would be a suitable starting point for a joint project with the IASB.

If the FASB decided to add to its agenda a joint project on insurance contracts, its objective would be to develop a common, high-quality standard that would address recognition, measurement, presentation and disclosure issues for insurance contracts and that would provide accounting and reporting guidance for both the issuer and the holder of an insurance contract. So far, the United States Generally Accepted Accounting Principles (US-GAAP) only require unbundling of insurance contracts in very limited circumstances, e.g., for reinsurance contracts containing prospective and retroactive

\footnotetext{
See IFRS 4.10 and .BC40 in connection with IFRS 4, Appendix A which defines a deposit component as a contractual component that is not accounted for as a derivative under IAS 39 and would be within the scope of IAS 39 if it were a separate instrument.

3 For a review of the relevant measurement models in existing IFRSs see DP, paragraph 221.

4 See IFRS 4.BC41 and DP, paragraph 223.
} 
components. ${ }^{5}$ The undertaking of a joint project together with the IASB could lead to a replacement of the limited US-GAAP guidance on unbundling by the broader IASB guidance, with the impact of this replacement still being uncertain. The FASB has not yet discussed, deliberated or reached any tentative conclusions about the IASB's preliminary views on insurance contracts. It expects to hold an Insurance Forum in spring 2008 to discuss the comment letters received on its Invitation to Comment and the IASB's DP. The FASB then plans to make an agenda decision in the third quarter of $2008 .^{6}$

\subsection{The Need for Unbundling of Insurance Contracts for Tax Purposes}

After a period of public consultation of interested parties the European Commission (2007a) has adopted a proposal aiming at modernising and simplifying the complex VAT rules for financial and insurance services on 28 November 2007. The proposal consists of both a Directive (2007b) and a Regulation (2007c). In the opinion of the European Commission the proposal shall create more certainty and security for Member States and for financial and insurance institutions. In March 2008 the European Commission (2008) published a background paper requested by the Council Presidency. The purpose of this paper is to provide information on the reasoning underlying the Commission's proposals on the VAT treatment of financial and insurance services.

The European Commission (2007b) identified two main objectives of its proposal:

- Increasing legal certainty for all parties concerned - from the insurance industry to national tax administrations - and reducing their administrative burden in correctly applying the VAT provisions on their services.

- Reducing the impact of hidden VAT in costs of insurance providers.

To achieve these objectives, the proposal contains the following measures:

- The clarification of the rules governing the exemption from VAT for insurance services by redefining the scope of the exempt insurance services. The proposal for a Regulation accompanying the proposal for a Directive expands the definitions of exempt services.

- The introduction of an industry specific exemption from VAT on cost sharing arrangements, including those which are cross border. This will enable insurance companies to pool their operations and to share costs between the group members without creating additional non-recoverable VAT.

- The option for taxation, so that the insurer can decide whether he wants to be fully taxable. Where he exercises the right, he will be able to deduct input VAT on his investments like any other economic operator. VAT taxable customers of insurance companies will also reduce their costs as they will be allowed to deduct the VAT paid on insurance services.

The option for taxation calls for unbundling because it would not be appropriate to tax life assurance premiums containing large deposit components with VAT as a whole. This kind of taxation would not fit into the VAT system. Irrespective of the option referred to above and because it shall only be exercisable for business insurance from 1 January 2012 a boundary between taxable and non-taxable premiums has to be defined in order to be able to apply the VAT system to insurance.

\footnotetext{
5 In US-GAAP, unbundling is referred to as bifurcating.

6 See http://www.fasb.org/project/research_projects.shtml\#insurance.
} 


\section{The Proposals concerning Unbundling of Insurance Contracts}

\subsection{The IASB's Proposal concerning Unbundling of Insurance Contracts}

Paragraph 228 of the DP contains a revised proposal for unbundling the insurance component and the deposit component of an insurance contract which is illustrated in figure 1:

\section{Figure 1 goes about here}

Accordingly, the DP refers to the following criteria for the decision whether to unbundle insurance contracts which contain a deposit component:

1. the degree of dependency between the components and

2. the arbitrariness of the measurement of the components.

The DP requires the insurer to unbundle if the insurance component and the deposit component are not interdependent or if the components are indeed interdependent but can be measured separately without arbitrariness, whereas the insurer is not permitted to unbundle if the insurance component and the deposit component are so interdependent that a separate measurement of the components would only be possible on an arbitrary basis. In this case the phase II standard on insurance contracts shall be applied to the whole contract.

\subsection{The European Commission's Proposal concerning the VAT Taxation of Insurance Contracts}

Except for the above-mentioned taxation option the European Commission's proposal does not address the unbundling problem. Neither the proposal for a Directive nor the proposal for a Regulation contain any statement about unbundling of insurance contracts.

\section{Literature Review: Existing Contributions to a Solution of the Unbundling Problem}

\subsection{The IASB's Discussion Paper}

The DP contains a proposal for unbundling the insurance component and the deposit component of an insurance contract without presenting any guidelines on how the process of unbundling shall be carried out. It does not provide any definitions of the terms 'not interdependent' and 'non-arbitrary measurability' so that it is not clear how insurers shall determine whether the interdependent components can be measured separately without arbitrariness and, if so, how the process of unbundling shall be carried out. So far, neither the IASB nor the literature have contributed to the interpretation of the definitions.

Furthermore, the IASB only provides inconsistent definitions of deposit components: The examples of deposit components given in the DP imply a very broad definition whereas the definition in the DP's Appendix I is narrow. According to paragraph 220 of the DP virtually all insurance contracts contain an implicit or explicit deposit component because the policyholder generally has to pay premiums in advance. By 
contrast, Appendix I of the DP defines a deposit component as 'a contractual feature that results in a repayment to policyholders, either individually or collectively' ${ }^{7}$, thus referring to the 'repayment to policyholders' as the distinguishing characteristic of a deposit component. When no such repayment to policyholders occurs, there shall be no unbundling of the insurance component and the deposit component. The DP, however, does not provide a definition of the term 'repayment to policyholders'. Instead, it contains possible examples of repayments of deposits to policyholders in paragraph 299.

Even a consistent definition of the deposit component would, however, not resolve the lack of clarity in connection with the necessity to unbundle the components of an insurance contract unless that definition would comprise solely deposit components which are either not interdependent or interdependent but separately measurable on a non-arbitrary basis.

\subsection{Literature concerning Accounting for Insurance Contracts}

So far, the existing literature concerning accounting for insurance contracts (e.g., Bacher \& Hofmann, 2007; Ebbers, 2004; Hasenburg \& Drinhausen, 2005; Hommel, 2003; IDW, 2003; Rockel, Helten, Loy \& Ott, 2005; Rockel \& Sauer, 2003, 2004, 2007) usually confines itself to describing the (proposed) regulations on unbundling of insurance contracts. In single cases the topic of unbundling is either explicitly left aside (e.g., Zimmermann \& Schweinberger, 2007), or the problems arising in connection with unbundling of insurance contracts are only addressed in a superficial manner (e.g., Engelaender \& Koelschbach, 2007; Surrey, 2006). Apparently, no solutions to the applicability problem have been published yet.

\subsection{Literature concerning the VAT Taxation of Insurance Contracts}

The existing literature concerning VAT (e.g., Poddar \& English, 1997) identifies the treatment of insurance services as one of the most difficult areas in the operation of this tax. Due to the inability to identify the appropriate tax base, Farmer \& Lyal (1994) and advocate general Fenelly ${ }^{8}$ point out that insurance transactions are inappropriate to be taxed under the VAT system. Therefore the literature (ITD, 2005; Le, 2003; Tait, 1988) assigns insurance transactions to the so-called "hard-to-tax sector".

As a consequence there are only a few papers dealing with the integration of insurance transactions into the VAT Council Directive. In 1997 Poddar \& English defined a tax base for VAT purposes, however by applying the cash-flow approach. Within the European Union, where the scheme has been closely considered, there are strong doubts as to its practicability and its compatibility with the VAT Council Directive (see Cnossen, 1998; Huizinga, 2002; Werle, 2002). Another theoretical consideration concerns only transactions of non-life insurance companies and can only be acknowledged as a partial solution (see Holzheu, 2000). Aside these approaches there are proposals to tax value added in insurance services by the addition method ${ }^{9}$ (see

\footnotetext{
7 IFRS 4, Appendix A contains a different definition: a contractual component that is not accounted for as a derivative under IAS 39 and would be within the scope of IAS 39 if it were a separate instrument. The definition in IFRS 4, therefore, aims at the accounting treatment of the deposit component.

8 See Opinion of Advocate General Fenelly, 11.06.1998, Case C-349/96, EuGHE 1999, p. I-973, paragraph 26.

9 By levying tax directly on the sum of wages and profits.
} 
Boadway \& Keen, 2003; Poddar, 2003) or by the direct subtraction method (see Neubig \& Adrion, 1993), which are not compatible with the VAT Council Directive.

Part of the literature concerning insurance contract law (see Adams, 2000; Hesberg \& Karten, 1999; Karten, Werber \& Winter, 1998; Rueckle, 1997) is discussing the separation of the components of insurance contracts. The proponents of separation propose to divide the insurance premium into three parts: risk business, investment business and service business. The intention is the separate administration of the premium components. A draft legislation referring to this proposition was entered into the German Federal Diet in 1997, but has not been successful. ${ }^{10}$ Due to the fact that the part of the premium paid for the service business is not shown separately for the risk business and for the investment business the proposal is inappropriate to identify the tax base for VAT purposes.

\section{An Applicable Approach for Unbundling of Insurance Contracts}

\subsection{Introduction}

The DP uses the criteria 'degree of dependency between the components' and 'arbitrariness of the measurement of the components' for the decision whether to unbundle insurance contracts which contain a deposit component. Our solution will follow these criteria in order to be compatible with the expected IFRS regulations. Accordingly, the deposit components have to be classified into different types. Dividing them into 'implicit' and 'explicit' deposit components seems to be the theoretically correct and suitable classification. ${ }^{11}$

\subsection{Explicit Deposit Components (Not Interdependent)}

An explicit deposit component is characterised by a saving process leading to an individual claim of the policyholder. The corresponding parts of the premiums are accumulated at interest and paid back when the policy matures.

Explicit deposit components only occur in life insurance and private accident insurance. In these cases it would be possible to take out another insurance policy for the same person insured, for the same time period and for the same risk, but without the deposit component. So, the insurance component and the deposit component are not interdependent although they are part of a uniform insurance contract. There is no problem of non-arbitrary measurability of the deposit component.

Certainly, measurement of the deposit component may be unsatisfactory because it is not independent of the measurement of the insurance component but results from the difference between the whole contract and the hypothetical corresponding contract without the deposit component. However, this seems to be the only possibility to measure the deposit component without arbitrariness. Any other measurement concept would obviously be in conflict with the non-interdependency criterion.

In most cases of explicit deposit components unbundling does not pose severe problems in practice because the corresponding contracts without the deposit

\footnotetext{
${ }^{10}$ See Bundestags-Drucksache 13/8163.

${ }^{11}$ For further details concerning implicit and explicit deposit components see Goettsche (forthcoming).
} 
components really exist, i.e., insurers offer such contracts although it is quite possible that they do not actively sell it.

\subsection{Implicit Deposit Components (Interdependent)}

Implicit deposit components are characterised by a saving process which systematically does not result in a (re)payment to the policyholder because the accumulated amount of money is used up during the normal average lifetime of the insurance contract (Altenburger, 2006). These deposit components are integral parts of the insurance contracts influencing their calculation not in an additive way - as this is the case with explicit deposit components - but in an integrative way. Therefore, they cannot be separated from the insurance components without destroying them or at least modifying them fundamentally; insurers do not offer corresponding insurance contracts without these deposit components. This situation seems to be equivalent to that described in the DP when referring to interdependent insurance and deposit components.

Implicit deposit components are part of all insurance contracts because of

- the time period needed for claims settlement and

- the fact that premiums (with few exceptions) have to be paid in advance.

Both factors enable insurers to invest a great deal of premium income at interest which results in lower premiums than those calculated without this interest.

Slightly different interest effects are part of the calculation of

- constant premiums for long-term insurance contracts in spite of increasing estimated claims over time.

In long-term life and permanent health insurance insurers in many countries regularly offer contracts with constant premiums which are increased only because of inflation but not because the persons insured get older which means a steadily higher mortality rate or illness rate respectively. During the first years of the contract parts of the premiums are put aside to subsidise (including accumulated interest) the later years; systematically no money is left at the originally agreed or estimated expiring date. On an average there do not remain any funds which could be paid back, at least if the duration of these insurance contracts is in accordance with the assumptions the premium calculation has been based on. In permanent health insurance the parts of the premiums put aside can be seen in the balance sheet as reserve for increasing age.

Both of the two implicit deposit components described first are also part of all hypothetical insurance contracts used to separate explicit deposit components and insurance components. This holds also true for the implicit deposit component described last if the insurance contract to be divided is a long-term life insurance contract calculated with constant risk premiums. (In health insurance there usually are no explicit deposit components.)

As all implicit deposit components and their corresponding insurance components are interdependent it has to be analysed whether they can be measured separately on a nonarbitrary basis.

\subsection{Non-arbitrary Measurement of Deposit Components}




\subsubsection{Non-arbitrary Measurability of Deposit Components}

The following analysis has to be carried out only for implicit deposit components because explicit deposit components, as stated above, do not pose severe measurement problems.

Implicit deposit components resulting from the time period needed for claims settlement and from the fact that premiums have to be paid in advance cannot reasonably be measured separately on a non-arbitrary basis. As premiums for insurance contracts not containing these deposit components would be higher, the parts of the premiums which correspond to these deposit components are negative. This does not allow a separation of the components on a non-arbitrary basis and, consequently, a nonarbitrary measurement.

Although implicit deposit components resulting from constant premiums for longterm insurance contracts in spite of increasing estimated claims over time are also part of uniform insurance contracts, they can be measured separately on a non-arbitrary basis because the relevant parts of the premiums and the amounts of the reserves are known in principle as results of the premium calculation. Certainly, the calculation methods applied in permanent health insurance often do not allow the specification of reserve amounts for individual policyholders, but it would be possible to calculate individual reserves for increasing age.

In contrast to common practice German health insurers will have to transfer reserves for increasing age to other health insurers if policyholders want to change their insurer during the first half of the year 2009. This follows from an amendment of section $178 \mathrm{f}$ of the German Insurance Contracts $\mathrm{Act}^{12}$ which has passed the legislative bodies recently. Thus, German health insurers will have to solve a measurement problem very similar to that discussed here.

\subsubsection{Practical Measurement of Deposit Components}

As only those implicit deposit components which result from constant premiums for long-term insurance contracts in spite of increasing estimated claims over time are separately measurable on a non-arbitrary basis, the measurement problem has to be solved for these deposit components only.

An implementable solution not requiring disclosure of all calculation details could refer to hypothetical insurance contracts analogous to the measurement of explicit deposit components. At least theoretically it would be possible to offer similar insurance contracts with increasing premiums instead of those with constant premiums.

Independent of an actual offer of such contracts the parallel insurance contracts have to be calculated for the same persons insured, for the same time periods and for the same risks as the contracts with constant premiums, but without building up and using up reserves, i.e. with annual premiums correctly reflecting the increasing mortality rate or illness rate respectively. These parallel insurance contracts constitute the insurance components of the long-term insurance contracts with constant premiums whereas the measurement of the deposit components results from the differences between the two corresponding insurance contracts concerned. According to the DP the whole contract shall be measured as insurance contract and the insurance component as the residual

\footnotetext{
${ }^{12}$ In the future section 204 of the German Insurance Contracts Act (revised at 21 September 2007).
} 
between the measurement of the whole contract and the measurement of the deposit component under IAS 39. If the same assumptions and estimates are used the results of both the DP's approach and our proposal should not differ.

\subsection{Consequences of the Separation of the Components for Taxation}

The solution just developed for accounting purposes is also applicable for tax purposes because it always results in a separation of premiums if unbundling has to be carried out. In this case only the part of the premium paid for the insurance coverage (risk premium) constitutes the correct tax base for sales tax, especially VAT; the other part of the premium has to be treated as non-taxable. If unbundling has not to be carried out the whole premium has to be taxed by sales tax, especially VAT (because the impossibility to separate the components of the contract for accounting purposes also holds true for tax purposes).

\section{Conclusions}

Unbundling of insurance contracts is a very complex issue. The proposed IFRS regulations on this matter and the (proposed) European VAT rules for financial and insurance services pose severe applicability problems.

This paper contains a proposal for a new approach of unbundling the insurance components and the deposit components of insurance contracts that is both compelling in its conceptual design and administratively simple to apply in practice. The principal design innovation is the way of distinction of different deposit components and their classification into different types. Dividing them into 'implicit' and 'explicit' deposit components delivers the theoretically correct results for unbundling of insurance contracts both for accounting and tax purposes. If the same assumptions and estimates are used the results of both the DP's approach concerning unbundling of insurance contracts and our proposal discussed in section 5 should be the same.

Nevertheless, the IASB should issue clearer regulations on unbundling than those proposed to avoid misunderstandings and inconsistent accounting procedures. In this context, a concerted action or a joint accounting standard with the FASB would be desirable to promote worldwide accounting uniformity. In addition, the (proposed) European VAT rules for financial and insurance services should be amended to clarify the treatment of insurance contracts and to include them correctly into the VAT system.

\section{References}

Adams, M. (2000). 'Vorschlaege zur Reform der kapitalbildenden Lebensversicherungen.' Neue Zeitschrift fuer Versicherung und Recht 3(2): 49-62.

Advocate General Fenelly (1998): Opinion delivered on 11 June 1998, Case C-349/96, EuGHE 1999, p. I-973. 
Altenburger, O. A. (2006). 'Neue Argumente gegen eine Praemientrennung.' In: T. Siegel, A. Klein, D. Schneider \& H.-P. Schwintowski (eds.), Unternehmungen, Versicherungen und Rechnungswesen, 129-141. Berlin: Duncker \& Humblot.

Bacher, D. F. \& A. Hofmann (2007). 'Versicherungsbilanzierung, quo vadis? Vorschlaege des IASB fuer einen Nachfolgestandard zu IFRS 4 Insurance Contracts.' Zeitschrift fuer Internationale Rechnungslegung 1(5): 311-317.

Barham, V., S. N. Poddar \& J. Whalley (1987). "The Tax Treatment of Insurance Under a Consumption Type, Destination Basis VAT.' National Tax Journal 40(2): 171-181.

Boadway, R. \& M. Keen (2003). 'Theoretical Perspectives on the Taxation of Capital Income and Financial Services: A Survey.' In: P. Honohan (ed.), Taxation of Financial Intermediation: Theory and Practice for Emerging Economies, 31-80. Washington, DC: The World Bank.

Bundestagsfraktion der SPD (1997). Entwurf eines Gesetzes zur Reform des Versicherungsvertragsgesetzes, Bundestags-Drucksache 13/8163, 2 July 1997.

Cnossen, S. (1998). 'Global Trends and Issues in Value Added Taxation.' International Tax and Public Finance 5(3): 399-428.

Ebbers, G. (2004). 'IFRS 4: Insurance Contracts.' Die Wirtschaftspruefung 57(23): 13771385.

Engelaender, S. \& J. Koelschbach (2007). 'Das Diskussionspapier des IASB zur Phase II des Versicherungsprojekts - Eine Analyse des vorgeschlagenen Bewertungsmodells -.' Kapitalmarktorientierte Rechnungslegung 7(7-8): 386-397.

European Commission (2007a). Summary of Results, Public Consultation on Financial and Insurance Services. Available at http://ec.europa.eu/taxation_ customs/resources/documents/common/consultations/tax/rep_financial_insurance_servi ces_en.pdf. [25 May 2008].

European Commission (2007b). Proposal for a Council Directive amending Directive 2006/112/EC on the common system of value added tax, as regards the treatment of insurance and financial services, Brussels, 5 October 2007. Available at http://eurlex.europa.eu/LexUriServ/LexUriServ.do?uri=COM: 2007:0747:FIN:EN:PDF. [25 May 2008].

European Commission (2007c). Proposal for a Council Regulation laying down implementing measures for Directive 2006/112/EC on the common system of value added tax, as regards the treatment of insurance and financial services, Brussels, 5 October 2007. Available at http://eur-lex.europa.eu/Lex UriServ/LexUriServ.do?uri=COM:2007:0746:FIN:EN:PDF. [25 May 2008]. 
European Commission (2008). Background Paper requested by the Council Presidency, Brussels, 5 March 2008. Available at http://ec.europa.eu/taxation _customs/resources/documents/common/publications/services_papers/other_papers/bac kground_paper_2414_08_en.pdf. [25 May 2008].

Farmer, P. \& R. Lyal (1994). EC Tax Law. Oxford: Oxford University Press.

Farny, D. (2000). Versicherungsbetriebslehre. 3rd ed. Karlsruhe: Versicherungswirtschaft.

FASB (2007a). An FASB Agenda Proposal: Accounting for Insurance Contracts by Insurers and Policyholders, Including the IASB Discussion Paper Preliminary Views on Insurance Contracts, Financial Accounting Series, Available at http://www.fasb.org/draft/ITC_Insurance_Contracts.pdf. [25 May 2008].

FASB (2007b). Research Projects, Accounting for Insurance Contracts. Available at http://www.fasb.org/project/research_projects.shtml\#insurance. [25 May 2008].

Goettsche, M. (forthcoming). Die Einbeziehung von Versicherungsumsaetzen in das Mehrwertsteuersystem der Europaeischen Gemeinschaft.

Hasenburg, C. \& A. Drinhausen (2005). 'IFRS 4 Versicherungsvertraege.' Der Konzern 3(10): 642-650.

Hesberg, D. \& W. Karten (1999). 'Der Gesetzentwurf zur Reform des deutschen Versicherungsvertragsgesetzes - Die Abspaltung der Kapitalanlage und des Risikogeschaefts.' Neue Zeitschrift fuer Versicherung und Recht 2(1): 1-9.

Holzheu. T. (2000). Die Einbeziehung der Schaden-/Unfallversicherung in das Umsatzsteuersystem. Karlsruhe: Versicherungswirtschaft.

Hommel, M. (2003). 'ED 5: Der neue Standardentwurf fuer Versicherungsvertraege ein Placebo mit Nebenwirkungen.' Betriebs-Berater 58(40): 2114-2121.

Huizinga, H. P. (2002). 'A European VAT on financial services?.' Economic Policy 17(35): 499-534.

IASB (2004). International Financial Reporting Standard 4 Insurance Contracts.

IASB (2007a). Discussion Paper Preliminary Views on Insurance Contracts. Part 1: Invitation to Comment and main text.

IASB (2007b). Discussion Paper Preliminary Views on Insurance Contracts. Part 2: Appendices.

IASB (2007c). Insurance Contracts. Available at http://www.iasb.org/Current +Projects/IASB+Projects/Insurance+Contracts/Insurance+Contracts.htm. [25 May 2008]. 
IDW (2003). 'Stellungnahme zu Exposure Draft ED 5: Insurance Contracts.' Die Wirtschaftspruefung 56(23): 1316-1321.

ITD (2005). 'The Value Added Tax - Experiences and Issues.' Background paper prepared for the International Tax Dialogue on the VAT, March 15-16, in Rome, Italy.

Karten, W., M. Werber \& G. Winter (eds.) (1998). Lebensversicherung und Geschaeftsbesorgung, Kolloquium in Memoriam Karl Sieg. Karlsruhe: Versicherungswirtschaft.

Le, T. M. (2003). 'Value Added Taxation: Mechanism, Design, and Policy Issues.' Paper prepared for the World Bank Course on Practical Issues of Tax Policy in Developing Countries, April 28-May 1, in Washington, DC, USA.

Neubig, T. S. \& H. L. Adrion (1993). 'Value Added Taxes and other Consumption Taxes: Issues for Insurance Companies.' Tax Analysts.

Poddar, S. N. (2003). 'Consumption Taxes: The Role of the Value-Added Tax.' In: P. Honohan (ed.), Taxation of Financial Intermediation: Theory and Practice for Emerging Economies, 345-380. Washington, DC: The World Bank.

Poddar, S. N. \& M. English (1997). 'Taxation of Financial Services Under a ValueAdded Tax: Applying the Cash-Flow Approach.' National Tax Journal 50(1): 89-112.

Rockel, W., E. Helten, H. Loy \& P. Ott (2005). Versicherungsbilanzen, Rechnungslegung nach HGB, US-GAAP und IFRS. Stuttgart: Schaeffer-Poeschel.

Rockel, W. \& R. Sauer (2003). 'IASB Exposure Draft 5: Insurance Contracts - Zur Versicherungsbilanzierung nach IFRS ab 2005.' Die Wirtschaftspruefung 56(20): 11081119.

Rockel, W. \& R. Sauer (2004). 'IFRS fuer Versicherungsvertraege (I) - Inhalte und Problemfelder von Phase 1.' Versicherungswirtschaft 59(4): 215-219.

Rockel, W. \& R. Sauer (2007). 'Bilanzierung von Versicherungsvertraegen - IASB Discussion Paper „Preliminary Views on Insurance Contracts“.' Die Wirtschaftspruefung 60(17): 741-749.

Rueckle, D. (1997). 'Rechnungslegung der Versicherungen und Ueberschussbeteiligung der Versicherten.' In: T. R. Fischer \& R. Hoemberg (eds.), Jahresabschluss und Jahresabschlusspruefung, Probleme, Perspektiven, internationale Einfluesse, 279-306. Duesseldorf: IDW.

Schmidt, P. (1999). Konsumbesteuerung durch Mehrwertsteuer, Zur konsumorientierten Ausgestaltung mehrwertsteuerlicher Erhebungstechnik. Bielefeld: Erich Schmidt.

Surrey, I. (2006). Die Bilanzierung von Versicherungsgeschaeften nach IFRS. Duesseldorf: IDW. 
Tait, A. A. (1988). The Value Added Tax: International Practice and Problems. Washington, DC: International Monetary Fund.

Werle. F.-J. (2002). An EU value added tax system for insurance services, CEA, Annual Report 2002/2003: 61-64.

Zimmermann, J. \& S. Schweinberger (2007). 'Zukunftsperspektiven der internationalen Rechnungslegung: Hinweise aus dem Diskussionspapier des IASB zur Bilanzierung von Versicherungsvertraegen.' Der Betrieb 60(40): 2157-2162. 
Table 1 Projected timetable for the new standard on insurance contracts

\begin{tabular}{|l|l|}
\hline End of Discussion Paper comment & 16 November 2007 \\
\hline Exposure Draft issued & 2009 \\
\hline Final Standard issued & 2010 \\
\hline Standard effective date & Yet to be determined \\
\hline
\end{tabular}

Source:

http://www.iasb.org/Current+Projects/IASB+Projects/Insurance+Contracts/Insurance+ Contracts.htm 
Table 2 Measurement and presentation consequences of unbundling

(a) measurement consequences:

(i) The insurance component is measured as an insurance contract.

(ii) The deposit component is measured under IAS 39 at either amortised cost or fair value. This might or might not differ from the basis used for insurance contracts.

(iii) An obligation to provide services (eg investment management) is typically measured under IAS 18 at the unearned part of any consideration received in advance. This may differ from current exit value if circumstances have changed significantly since inception, or if an initial measurement at current exit value led to a profit at inception.

(iv) For deposit components measured at amortised cost, the related incremental transaction costs are deducted in determining the initial carrying amount, not recognised as an expense.

(b) presentation consequences, discussed in chapter 7 :

(i) Premium receipts for the deposit component are presented as changes in the deposit liability, not as revenue. Premium receipts for the insurance component are typically presented as revenue in current practice, but chapter 7 discusses whether this should continue.

(ii) If the deposit component is regarded as third-party funds under management, rather than as a direct obligation of the insurer, the deposit component might be reported off balance sheet. This is how most fund managers account for mutual funds that they manage.

Source: Discussion Paper "Preliminary Views on Insurance Contracts. Part 1: Invitation to Comment and main text", paragraph 223(a) and (b) 
Figure 1 The DP's proposed regulations for unbundling the components of insurance contracts

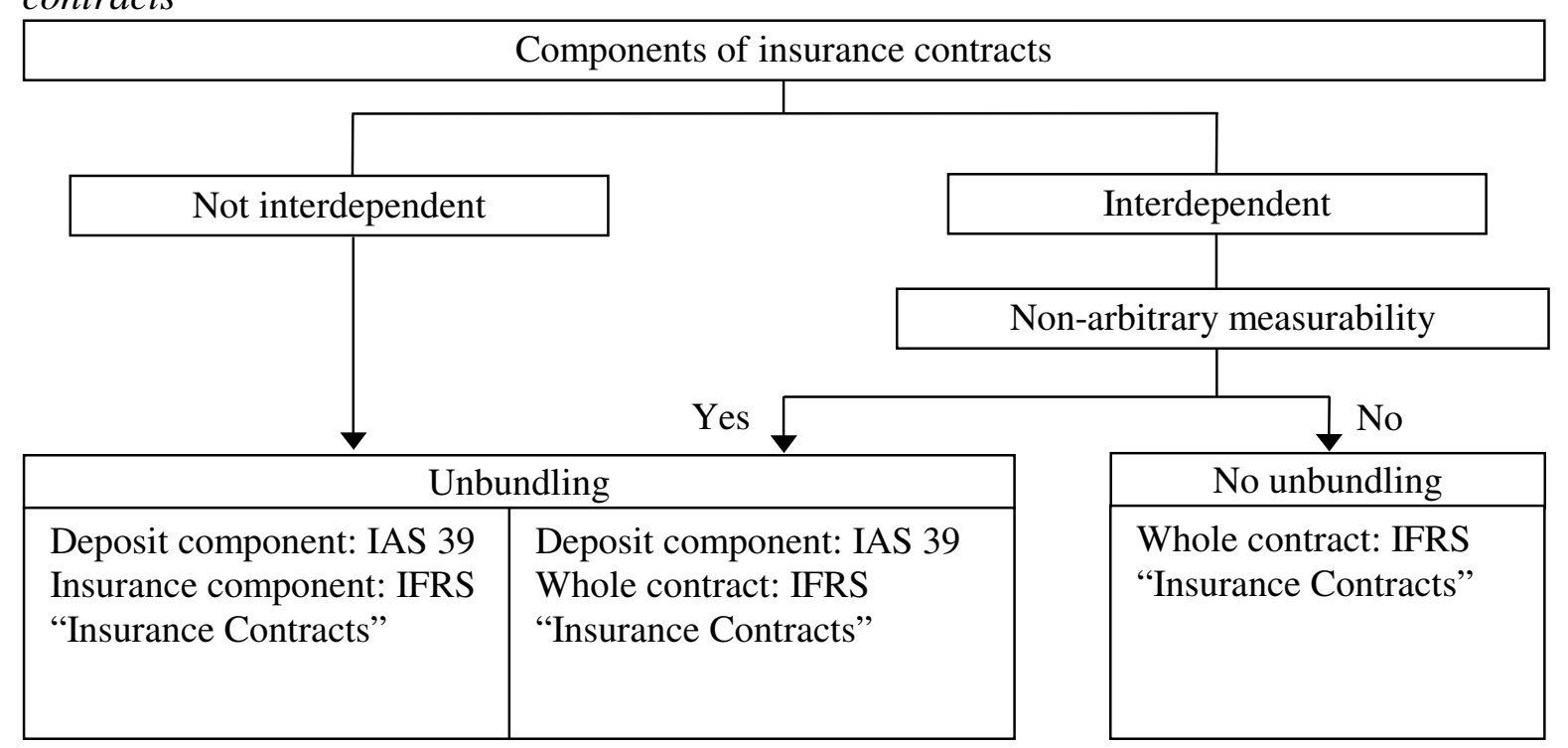

Source: the authors' representation 